\title{
ASSESSMENT OF OPTIMUM VALUE FOR DIP ANGLE AND LOCKING RATE PARAMETERS IN MAKRAN SUBDUCTION ZONE
}

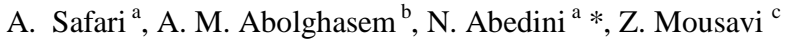 \\ ${ }^{a}$ Department of Surveying and Geomatics Engineering, University of Tehran, Iran - (asafari, nazilaabedini)@ut.ac.ir \\ ${ }^{\mathrm{b}}$ Facility of geosciences, Ludwig-Maximilians-Universitat München, Germany - amir.a@lmu.de \\ ${ }^{c}$ Department of earth sciences, Institute for advanced studies in basic sciences, Zanjan, Iran - z.mousavi@iasbs.ac.ir
}

KEY WORDS: Rigid block modelling, GPS observations, Seismicity, Velocity vectors, Dip angle, Makran subduction zone

\begin{abstract}
:
Makran subduction zone is one of the convergent areas that have been studied by spatial geodesy. Makran zone is located in the South Eastern of Iran and South of Pakistan forming the part of Eurasian-Arabian plate's border where oceanic crust in the Arabian plate (or in Oman Sea) subducts under the Eurasian plate ( Farhoudi and Karig, 1977). Due to lack of historical and modern tools in the area, a sampling of sparse measurements of the permanent GPS stations and temporary stations (campaign) has been conducted in the past decade. Makran subduction zone from different perspectives has unusual behaviour: For example, the Eastern and Western parts of the region have very different seismicity and also dip angle of subducted plate is in about 2 to 8 degrees that this value due to the dip angle in other subduction zone is very low. In this study, we want to find the best possible value for parameters that differs Makran subduction zone from other subduction zones. Rigid block modelling method was used to determine these parameters. From the velocity vectors calculated from GPS observations in this area, block model is formed. These observations are obtained from GPS stations that a number of them are located in South Eastern Iran and South Western Pakistan and a station located in North Eastern Oman. According to previous studies in which the locking depth of Makran subduction zone is $38 \mathrm{~km}$ (Frohling, 2016), in the preparation of this model, parameter value of at least $38 \mathrm{~km}$ is considered. With this function, the amount of 2 degree value is the best value for dip angle but for the locking rate there is not any specified amount. Because the proposed model is not sensitive to this parameter. So we can not expect big earthquakes in West of Makran or a low seismicity activity in there but the proposed model definitely shows the Makran subduction layer is locked.
\end{abstract}

\section{INTRODUCTION}

Makran zone is located in the East of Iran and South of Pakistan forming the southern part of Eurasian-Arabian plate's border where oceanic crust in the Arabian plate (or in Oman Sea) subducts under the Eurasian plate (Farhoudi and Karig., 1977). Makran subduction zone is one of the largest areas in the world with approximately $350 \mathrm{~km}$ accretionary prism. This wedge has a mix of silica sediments deposited in the Gulf of Oman (Harms et al., 1984).

Makran subduction zone as its unusual behaviour has different perspectives including that Eastern and Western parts have very different seismicity activity patterns. Eastern part of Makran with the record of historical earthquakes occurrence is different from the western part that apparently is without large earthquakes. Moreover, Makran is characterized by an extremely shallow subduction angle (Kopp et al., 2000). Recent seismic reflection profiles across the Makran subduction zone showed that the Makran subduction zone has a dip angle between 2 and 8 .
Highlighting the fact that whether the West of Makran has the aseismic subduction, or the occurrence of large earthquakes is in beyond the historical records (locking) is one of the big challenges in Makran seismotectonics. Also, this feature that dip angle of subduction is extremely low make this accretionary wedge especially interesting and makes it different from other subduction zones. The aim of this study was to determine the best value of the parameters distinguishing the Makran subduction zone from other subduction zones. Rigid block modelling method was used to prepare the model of the motion of the Makran area affected by the pressure of the subduction zone. By comparing the obtained model with the results of GPS observations conducted in this area, we can obtain the best possible value for the angle which the oceanic plate subducts under crustal plate in the Makran region. We also will try to obtain the best possible value for the percentage of locking rate of subducted plate using the same method to obtain evidence West of Makran subducts with no tremble or the occurrence of large earthquakes in advance.

\footnotetext{
* Corresponding author
} 


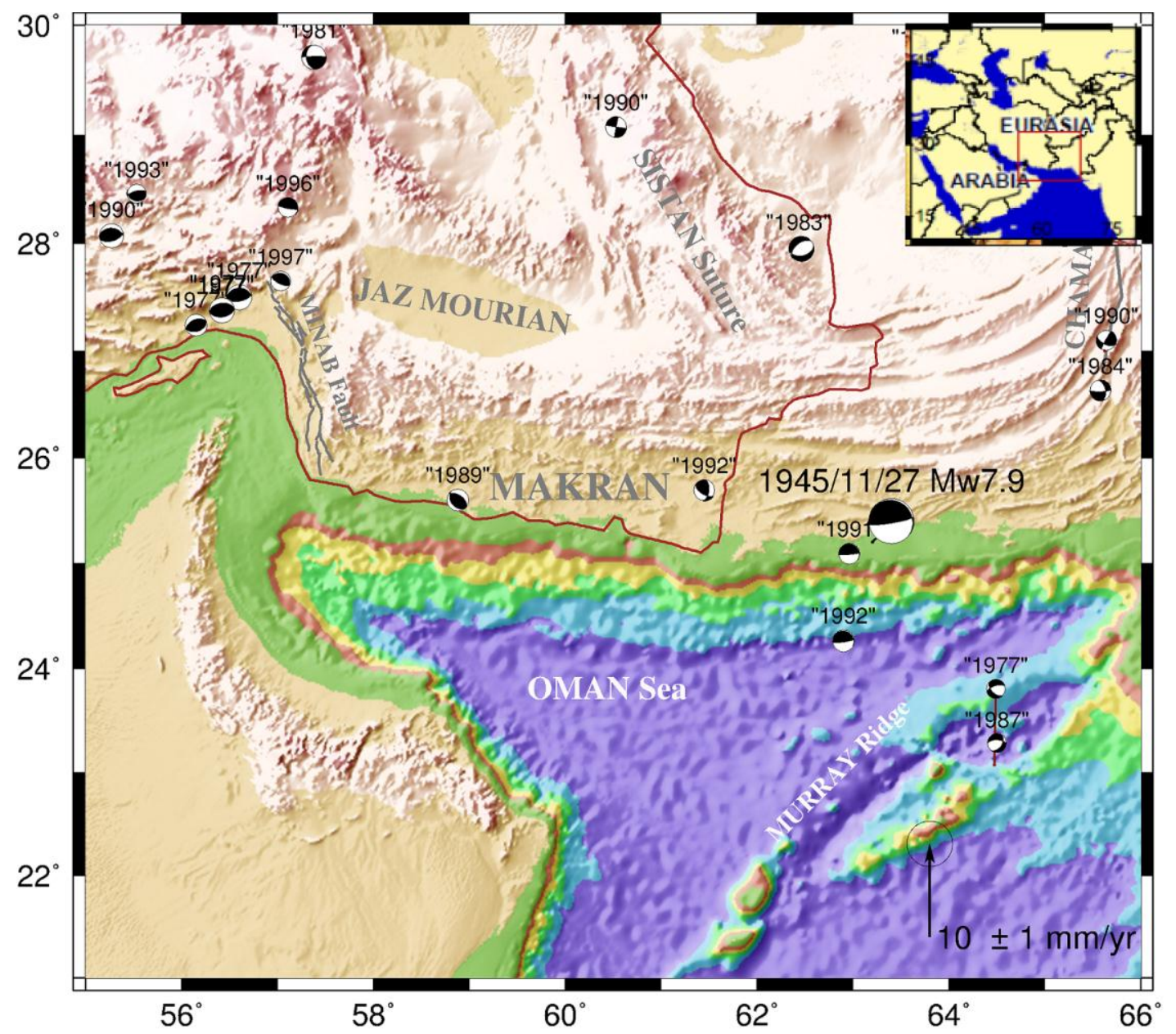

Figure 1. 3D topographic map of Makran region with a focal mechanism of earthquakes with $\mathrm{Mw} \geq 6$ from Harvard's catalogue (Dziewonski et al., 1983). The major fault zones are determined.

\section{SEISMOTECTONICS OF MAKRAN SUBDUCTION ZONE}

The Makran accretionary complex has developed throughout the Cainozoic at the convergent margin between the Arabian and the Eurasian plates. Its evolution has been coeval with the Himalayan orogeny (Harms et al., 1984). Its first evolutionary phase (late Oligocene to middle Miocene) was characterized by turbiditic deposition of quartzolithic sands and muds. The accretionary wedge grew seaward by accretion of trench fill sediments. Accommodates convergence of the Arabian plate beneath the Eurasian plate at a rate of about $4 \mathrm{~cm} \mathrm{yr}^{-1}$ over the past 3 Myr (DeMets et al., 1990; Kopp et al, 2000).

Also, the rate of convergence in Makran partially increases as part of the West (36.5 millimetres per year near the Strait of Hormuz) to the East (42.0 millimetres per year in the eastern border of Makran) (Demets et al., 1990; Zarifi, 2007). Border areas of Makran subduction zone have relatively complex tectonics features. Since the middle Pleistocene the coastal Makran has experienced uplift and normal faulting, while in the seaward part accretion has continued to this day (Harms et al., 1984). At present the accretionary complex has an along-strike extent of about $1000 \mathrm{~km}$ and is separated by two fault systems from regions of active continent-continent collision (the Zagros and Himalaya).
So that the right-lateral Minab-Zendan fault (Figure 1) connects Western side of the Makran to Zagros zone (White and Ross., 1979). Eastern edge of the Strait of Hormuz separates continental crust of Arabia from its oceanic crust (Oman Sea) (White and Ross., 1979). Chaman fault and left-lateral OrnachNal fault make Eastern border of Makran that has compatibility with moving between the Eurasian plate and the Western part of Indian plate (Figure 1) and Murry mid-Atlantic ridge specifies southern part of the border between the Arabian and Indian plate (De Mets and Gordon., 1990).

Instrumental seismicity, historical large earthquakes and focal mechanism of earthquakes show that Makran subduction zone from West to East can have segmentation and clear differences in seismic behaviour can be seen (Byrne et al., 1992; Zarifi, 2007). This segmentation in Makran subduction zone can be marked with the Sistan suture zone (Figure 1). All of Eastern Makran have historically been interrupted with mega thrust earthquakes and now has very little seismic activity that earthquakes are small and medium-sized in its forearc region. Although some earthquakes occur in the subducted plate in the East of Makran, but most seismic activity occurs along the plate boundary. Only great instrumental earthquake (Ms greater than 7.7) registered in the Makran is the earthquake in 1945 as a result of over-thrust between two plates occurred in East of Makran. In contrast, West of Makran has not have any large historical or instrumental earthquakes along the plate boundary 
except a suspicious earthquake in 1483 (Ambraseys and Melville, 2005; Byrne. Et al., 1992) that is possibly occurred in this area. Almost all earthquakes occur in the Western part of the subducted plate in an average depth and often have normal fault mechanism.

Lack of plate boundary earthquakes in West of Makran can completely reflect earthquakes with no tremble or current plateboundary locking and very long return period earthquakes. If the second hypothesis is correct, the horrific earthquake risk threatens region (Byrne et al., 1992) and we can be refer to some evidence which shows the second hypothesis is true. Lack of small thrust earthquakes along the plate boundary of West of Makran (Byrne et al., 1992) and also existence of a young raised marine terrace along parts of the western coasts of Makran as East of Makran (Page et al., 1979) may indicate severe locking between two plates and accumulation of friction energy with no small earthquakes.

However, some researchers believe that this evidence cannot prove a compelling reason for strong coupling and the probability of large earthquakes in West of Makran subduction zone. Because the large earthquakes are not the only factor in the development of marine terrace, so that a well-known marine terraces that have been formed due to global changes in sea levels.
As well, all major earthquakes do not cause visible marine terraces (for example, the 1960 Chilean earthquake, Byrne et al., 1992). On the hand, the Makran subduction zone has a considerable amount of accreted sediments recently accumulated and tightened. Such deposits which are not firm represent the steady-slip characteristics with no seismic behaviour. However, Byrne et al (1992) made clear that cumulative and subducted sediments in Makran have dehydration and is stiff enough so that they can create large earthquakes between plates.

\section{GPS DATA}

In this study, taking into account the GPS stations located in this region, the velocity vectors calculated for the stations in the software GAMMIT-GLOBK is used as input (Frohling, 2016). Given that the station used should be almost near subduction zone, some of the following stations in light of the coordinates cannot be used (table 1).

Because we want to obtain movement of the Makran block due to pressure over the subduction zone relative to Arabian plate, so we must rotate velocity vectors relative to Arabian plate in which such vectors are as follows in Table 2 .

\begin{tabular}{|c|c|c|c|c|c|c|c|}
\hline Longitude & Latitude & $\begin{array}{c}\text { East } \\
\text { (mm/year) }\end{array}$ & $\begin{array}{c}\text { East } \\
\text { uncertainty } \\
\text { (mm/year) }\end{array}$ & $\begin{array}{c}\text { North } \\
(\mathrm{mm} / \text { year })\end{array}$ & $\begin{array}{c}\text { North } \\
\text { uncertainty } \\
\text { (mm/year })\end{array}$ & Correlation & Name \\
\hline 67.11287 & 24.93144 & 6.45 & 0.14 & 29.03 & 0.11 & 0.004 & KCHI \\
\hline 66.60140 & 29.10583 & 4.78 & 0.75 & 17.87 & 0.72 & 0.018 & KALT \\
\hline 66.22359 & 26.19502 & 5.42 & 0.50 & 29.16 & 0.47 & 0.012 & LAKC \\
\hline 66.12940 & 26.18228 & 6.40 & 0.76 & 25.06 & 0.70 & 0.017 & SHFD \\
\hline 65.60532 & 26.39270 & 5.10 & 0.86 & 13.04 & 0.80 & 0.035 & ZHAO \\
\hline 65.22591 & 26.44925 & 5.12 & 1.28 & 12.37 & 1.18 & -0.054 & BEDI \\
\hline 64.63393 & 25.20879 & 2.89 & 1.16 & 13.16 & 1.08 & 0.014 & ORMA \\
\hline 64.40259 & 28.88538 & 0.85 & 3.49 & -0.15 & 3.36 & 0.066 & DALN \\
\hline 64.10960 & 26.97782 & 1.56 & 0.78 & 1.85 & 0.73 & 0.033 & PANG \\
\hline 63.46840 & 25.25882 & 4.01 & 1.11 & 17.14 & 0.97 & 0.024 & PASN \\
\hline 62.32033 & 25.14408 & 4.99 & 0.34 & 7.69 & 0.31 & 0.036 & GWAD \\
\hline 62.31832 & 27.39024 & 2.72 & 0.15 & 2.72 & 0.15 & 0.000 & SRVN \\
\hline 61.71592 & 30.84128 & 2.25 & 0.23 & 2.87 & 0.22 & 0.008 & ZABL \\
\hline 60.65113 & 25.28080 & 2.77 & 0.22 & 6.21 & 0.37 & 0.010 & CHBR \\
\hline 59.44851 & 27.48216 & 2.48 & 0.20 & 6.39 & 0.32 & 0.002 & GLMT \\
\hline 58.88126 & 23.93733 & -0.22 & 0.22 & 7.40 & 0.20 & -0.003 & FHRJ \\
\hline 57.76989 & 25.63753 & 1.35 & 0.12 & 13.71 & 0.13 & 0.010 & JASC \\
\hline 56.30735 & 27.20391 & 4.07 & 0.21 & 24.86 & 0.19 & 0.001 & BAGS \\
\hline 56.11234 & 22.18646 & 5.90 & 0.27 & 26.12 & 0.11 & 0.008 & YIBL \\
\hline
\end{tabular}

Table1. GPS velocities relative to the stable Eurasian plate as defined by Altamimi et al (2012). 


\begin{tabular}{|c|c|c|c|c|c|c|c|}
\hline Longitude & Latitude & $\begin{array}{c}\text { East } \\
(\mathrm{mm} / \mathrm{year})\end{array}$ & $\begin{array}{c}\text { East } \\
\text { uncertainty } \\
(\mathrm{mm} / \text { year })\end{array}$ & $\begin{array}{c}\text { North } \\
(\mathrm{mm} / \text { year })\end{array}$ & $\begin{array}{c}\text { North } \\
\text { uncertainty } \\
(\mathrm{mm} / \text { year })\end{array}$ & Correlation & Name \\
\hline 60.65113 & 25.28080 & -4.84 & 0.22 & -21.14 & 0.30 & 0.818 & CHAB \\
\hline 57.76989 & 25.63753 & -4.64 & 0.12 & -11.97 & 0.13 & 0.010 & JASK \\
\hline 62.32033 & 25.14408 & -2.26 & 0.34 & -28.39 & 0.31 & 0.036 & GWAD \\
\hline 63.46830 & 25.25882 & -3.40 & 1.11 & -11.77 & 0.97 & 0.024 & PASN \\
\hline 64.63393 & 25.20879 & -4.81 & 1.16 & -16.37 & 1.08 & 0.814 & ORMA \\
\hline 58.88126 & 28.93733 & -4.14 & 0.22 & -18.93 & 0.20 & 0.003 & FHRJ \\
\hline 59.44851 & 27.48216 & -2.57 & 0.26 & -20.27 & 0.32 & 0.002 & CLMT \\
\hline 62.31832 & 27.4821 & -2.97 & 0.15 & -25.5 & 0.15 & 0.001 & SRVN \\
\hline
\end{tabular}

Table 2. Velocity vectors rotated relative to the plane of Arabia and used in the model

\section{METHODS}

In this study, rigid block modelling method is used to determine the best value of the locking rate and dip angle parameters in the Makran subduction zone. In this way, we investigate the plate's movements. Our study area is the small plates (micro plate).About the micro plate, more GPS stations located in the regions are under the influence of deformation, so modelling of movement of small plate needs attention to the effects of deformation in the boundary lines (McClusky et al. 2000). Describing the motion of a flexible lithospheric plate is based on Euler's theorem. In this case, the motion on the sphere is shown with a simple rotation around an axis through the center of the appropriate sphere is appeared (Turcotte and Schubert, 2014). So lithospheric plate's movement at any time is shown with rotation around an axis is through the center of the Earth that it is called the axis of rotation. The axis of rotation divided the Earth's surface into two opposite points that is called Euler pole or rotating pole.

So each lithosphere plate consists of two rotating Euler poles and systems of orbits and meridians. The characterises of movement that determines rotations of a plate or block around the axis of rotation, are the coordinates of one of the poles of rotation on the sphere (longitude $\lambda$ and latitude $\Phi$ ) and a magnitude of speed of rotation angle $\alpha$ (with degree unit in 1 million years) or 3 component Euler vector in the coordinate system in the center of the earth as $\Omega=\left(\omega_{x}, \omega_{y}, \omega_{z}\right)$, that here the orientation of system from origin reflects the state of the rotation poles on the sphere and the magnitude is equal to the velocity of rotation angle of the block relative to the pole. There are several models to estimate the rate of deformation on the surface of fault that we can refer the simplified models including isotropic environment (Okada, 1985) and homogeneous models with spherical and layer structure of the Earth (Pollitz, 1996).
Since the modelling deformation is done to determine the movement of micro plate in the area not more than 100, we can use simple approach of Okada (1985) for assumed distances (error less than 2\%) and the layer structure (less than 20\%). Tools of block modelling used in this study are called TDEFNODE designed by McCaffrey, 2013. It is based on the routines of Okada, 1985; 1992 and models elastic lithospheric block rotations and strains, as well as locking rate or coseismic slip on block-bounding faults.

By TDEFNODE software which is FORTRAN code, we can determine the movement of tectonic blocks (Apel et al., 2006; Reilinger et al., 2006; Loveless and Meade, 2010; McCaffrey et al., 2013).

Block motions is determined by Euler rotation pole. Block modelling approach consists of several steps: First, the block situation and fault between blocks is determined, and then Euler pole of the moving plate is determined. The GPS velocity vectors in block are used to determine location and rate of rotation relative to the axis of rotation, so the proposed model can be built using the range of plate.

In this study, subduction zone is considered as dependent fault between the two blocks. Due to the location of GPS stations and coordinates of subduction zone in the Digital model of plate boundaries (Peter Bird, 2003) including points where the depth of the sea suddenly becomes much, we can obtain coordinates of dependent fault between the two blocks. After determining the coordinates of the blocks and to more accurately determine the position of the blocks, Digital model of plate boundaries (Peter Bird, 2003) was used.

According to the observations obtained from GPS stations in the area and velocity vectors obtained from these observations, a noticeable point is significant difference in the magnitude of the velocity vectors obtained from GPS stations located in West of Makran i.e. JASK and CHAB and GWAD AND stations in East of Makran i.e. ORMA and PASN stations. For this reason, to get better results obtained from the proposed model, block is divided into two blocks: East and West Makran. 
Velocity vectors used in this study are velocities relative to the stable Eurasian plate as defined by Altamimi et al (2012) (Frohling, 2016), but what concerned us is that we have the velocity vectors relative to the Arabian plate to be able to determine displacement of Makran block relative to the Arabian plate. For this, we consider oceanic block constant and rotate velocity vectors and obtain new vectors relative to Arabian reference frame.

To form the block model, we need block Euler pole. Makran block is part of the Eurasia plate. According to the previous studies, the amount calculated for Euler pole in Eurasian plate is than the ITRF 2000 reference frame is equals to $(\lambda=13.7, \Phi$ =24.6, $\Omega=0.5$ ) (Vernant, 2003). But because the velocity vectors are calculated relative to Arabian plate, Euler pole for the Eurasian plate should be calculated relative to Arabian plate. So Euler pole of Makran block relative to the Arabian reference frame is defined by these coordinates $(\lambda=-56.94, \Phi=-$ 30.52 ) on the sphere and great speed of the rotation angle is $\Omega=-0.5$ (mm / year).

So by having Euler pole of the Eurasian relative to the Arabian plate, we can obtain the movement of the Makran tectonic block. This model is sensitive to the three parameters: thickness of subduction layer, dip angel and locking rate. In this study, the thickness of subduction layer is at least $38 \mathrm{~km}$ (Frohling, 2016).

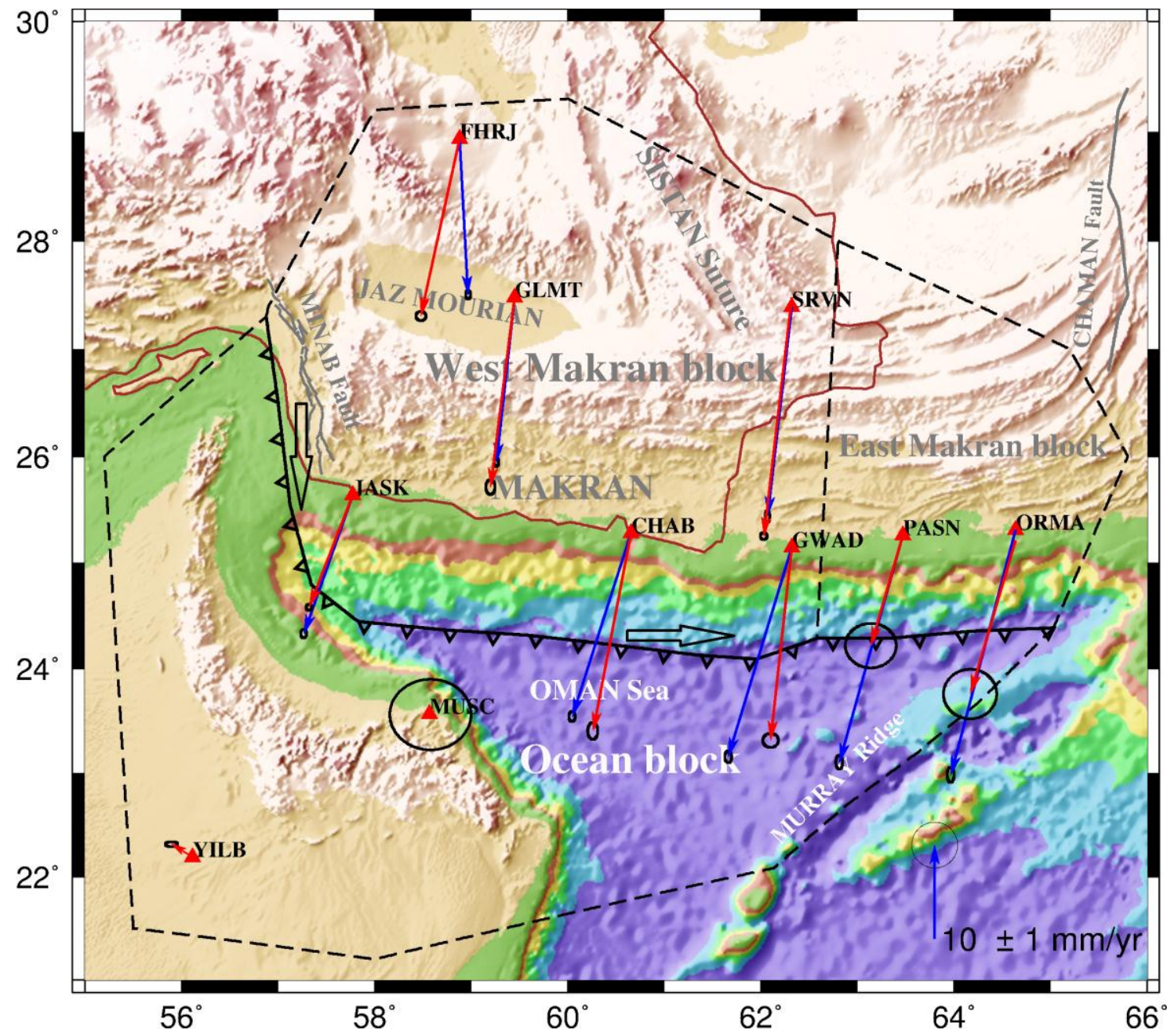

Figure 2. The velocity vectors of GPS observations are shown in red and the velocity vectors of the best proposed model are shown in blue.

\section{DISSCUTION AND RESULTS}

According to the basic premise that we have in the implementation of the model that the thickness of the crust in the Oman Sea and the forearc region is at least $38 \mathrm{~km}$ (Frohling, 2016) and according to the results of the models made for different values of the parameters, we could reach the optimum value for these parameters. In order to implementation of these models, the inverse method is used; it means that all possible models of these two parameters in different modes are considered. Locking rate range differs from 0 to 100 percent and the acceptable range for dip angle is $\left[0^{\circ}, 90^{\circ}\right]$. In this case, by changing these two parameters in the related model script, 290 different models are created. Then the Root Mean Square (RMS) value of the differences between proposed model and 
GPS observation is computed. The lowest value of RMS will give us the optimum value of these two parameters. The best state of the obtained GPS station's velocity vectors of the proposed model is shown in fig. 2.

Using the data set by Engdahl and Vilasner (2002) and gravity anomalies (Zarifi, 2007) showed that subduction in the East of Makran has little dip in about 2 degrees first. He believes that the dip of the subducted plate in place in the West of Makran subduction beneath the crust cannot be determined. Also the results of this study show that subduction in the West of Makran is started with low dip angle of about 2 degree.
In this study the proposed model is not sensitive to the locking rate so we can't expect big earthquakes in West of Makran or a low seismicity activity in there but the proposed model definitely shows the Makran subduction layer is locked because there is an extreme increase in RMS value when the locking rate parameter in $0 \%$. And due to the big difference in velocity vectors for observation stations in East and West of Makran and also good agreement with the observed velocity vectors in West of Makran, the results of the models are compatible for West of Makran. Thus obtained results from this study is compatible with the study of Byrne et al (1992).

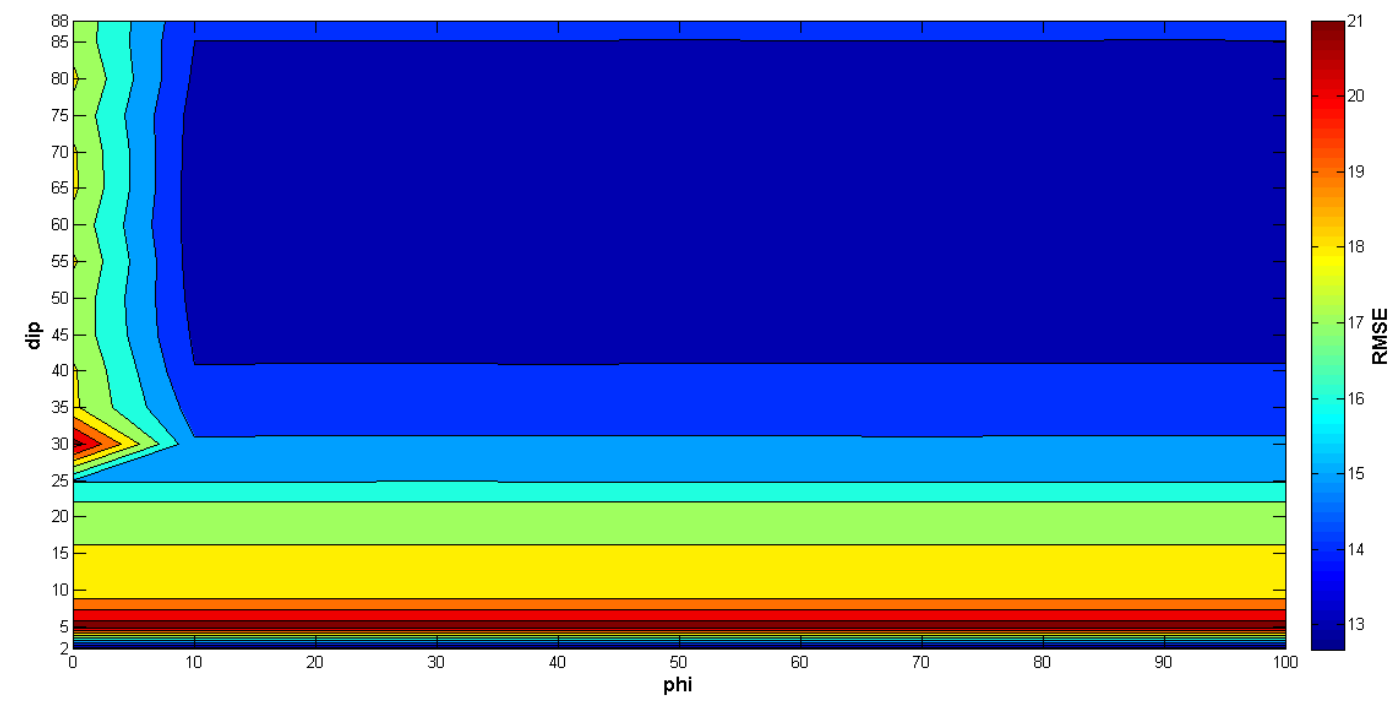

Figure 3.The graph represents the computed RMS of the differences between the models obtained from different amount of two parameters (dip angle and locking rate) and GPS observation. Vertical and horizontal axises respectively represent dip angle and locking rate. The lowest value of RMS will give us the optimum value of dip angle parameter that it is 2 degree. Also the graph shows the model is not sensitive to the locking rate but definitely shows the Makran subduction layer in locked.

\section{REFERENCES}

Altamimi, Z., Collilieux, X. \& Métivier, L. J Geod (2011) 85: 457. Doi: 10.1007/s00190-011-0444-4.

Altamimi, Z., Métivier, L. and Collilieux, X., 2012. ITRF2008 plate motion model.Journal of Geophysical Research: Solid Earth, 117(B7).

Ambraseys, N.N. and Melville, C.P., 2005. A history of Persian earthquakes. Cambridge university press

Apel, E.V., Bürgmann, R., Steblov, G., Vasilenko, N., King, R. and Prytkov, A., 2006. Independent active microplate tectonics of northeast Asia from GPS velocities and block modeling Geophysical Research Letters, 33(11)

Bird, P., 2003. An updated digital model of plate boundaries Geochemistry, Geophysics, Geosystems, 4(3)
Byrne, D.E., Sykes, L.R. and Davis, D.M., 1992. Great thrust earthquakes and aseismic slip along the plate boundary of the Makran subduction zone. Journal of Geophysical Research: Solid Earth, 97(B1), pp.449-478.

DeMets, C., Gordon, R.G., Argus, D.F. and Stein, S., 1990. Current plate motions. Geophysical journal international, 101(2), pp.425-478.

Dziewonski, A.M., Friedman, A., Giardini, D. and Woodhouse, J.H., 1983. Global seismicity of 1982: centroid-moment tensor solutions for 308 earthquakes. Physics of the earth and planetary interiors, 33(2), pp.76-90.

Engdahl, E.R., van der Hilst, R. and Buland, R., 1998. Global teleseismic earthquake relocation with improved travel times and procedures for depth determination. Bulletin of the Seismological Society of America, 88(3), pp.722-743.

Farhoudi, G. and Karig, D.E., 1977. Makran of Iran and Pakistan as an active arc system. Geology, 5(11), pp.664-668. 
Frohling, E. and Szeliga, W., 2016. GPS constraints on interplate locking within the Makran subduction zone. Geophysical Journal International, 205(1), pp.67-76.

Harms, J.C., Cappel, H.N. and Francis, D.C., 1984. The Makran coast of Pakistan: its stratigraphy and hydrocarbon potential. Marine geology and oceanography of Arabian Sea and coastal Pakistan, 3, p.27.

Heidarzadeh, M., Pirooz, M.D., Zaker, N.H., Yalciner, A.C., Mokhtari, M. and Esmaeily, A., 2008. Historical tsunami in the Makran Subduction Zone off the southern coasts of Iran and Pakistan and results of numerical modeling. Ocean Engineering, 35(8), pp.774-786.

Kopp, C., Fruehn, J., Flueh, E.R., Reichert, C., Kukowski, N., Bialas, J. and Klaeschen, D., 2000. Structure of the Makran subduction zone from wide-angle and reflection seismic data. Tectonophysics, 329(1), pp.171-191.

Loveless, J.P. and Meade, B.J., 2010. Geodetic imaging of plate motions, slip rates, and partitioning of deformation in Japan. Journal of Geophysical Research: Solid Earth, 115(B2).

McCaffrey, R., King, R.W., Payne, S.J. and Lancaster, M., 2013. Active tectonics of northwestern US inferred from GPS-derived surface velocities. Journal of Geophysical Research: Solid Earth, 118(2), pp.709-723.

McClusky, S., Balassanian, S., Barka, A., Demir, C., Ergintav, S., Georgiev, I., Gurkan, O., Hamburger, M., Hurst, K., Kahle, H. and Kastens, K., 2000. Global Positioning System constraints on plate kinematics and dynamics in the eastern Mediterranean and Caucasus. Journal of Geophysical Research: Solid Earth, 105(B3), pp.5695-5719.

Okada, Y., 1985. Surface deformation due to shear and tensile faults in a half-space. Bulletin of the seismological society of America, 75(4), pp.1135-1154.

Page, W.D., Alt, J.N., Cluff, L.S. and Plafker, G., 1979. Evidence for the recurrence of large-magnitude earthquakes along the Makran coast of Iran and Pakistan. Tectonophysics, 52(1-4), pp.533-547.

Pollitz, F.F., 1996. Coseismic deformation from earthquake faulting on a layered spherical Earth. Geophysical Journal International, 125(1), pp.1-14.

Reilinger, R., McClusky, S., Vernant, P., Lawrence, S., Ergintav, S., Cakmak, R., Ozener, H., Kadirov, F., Guliev, I., Stepanyan, R. and Nadariya, M., 2006. GPS constraints on continental deformation in the Africa-Arabia-Eurasia continental collision zone and implications for the dynamics of plate interactions. Journal of Geophysical Research: Solid Earth, 111(B5).

Turcotte, D.L. and Schubert, G., 2014. Geodynamics. Cambridge University Press.

Vernant, P., Nilforoushan, F., Hatzfeld, D., Abbassi, M.R., Vigny, C., Masson, F., Nankali, H., Martinod, J., Ashtiani, A., Bayer, R. and Tavakoli, F., 2004. Present-day crustal deformation and plate kinematics in the Middle East constrained by GPS measurements in Iran and northern Oman. Geophysical Journal International, 157(1), pp.381-398.
White, R.S. and Ross, D.A., 1979. Tectonics of the western Gulf of Oman. Journal of Geophysical Research: Solid Earth, 84(B7), pp.3479-3489.

Zarifi, Z., 2007. Unusual subduction zones: Case studies in Colombia and Iran. 